\title{
The Evolution of Booster on the Assertive Speech Act Used in Two Decades Version of Translation
}

\author{
Ilham \\ Linguistics Postgraduate Programme \\ Universitas Sebelas Maret \\ J1. Ir. Sutami, Surakarta, Indonesia \\ iamilham88@student.uns.ac.id \\ Diah Kristina \\ Faculty of Cultural Sciences \\ Universitas Sebelas Maret \\ Jl. Ir. Sutami, Surakarta, Indonesia \\ kristina_diah@yahoo.com
}

\author{
M. R. Nababan \\ Faculty of Cultural Sciences \\ Universitas Sebelas Maret \\ Jl. Ir. Sutami, Surakarta, Indonesia \\ amantaradja@gmail.com \\ Tri Wiratno \\ Faculty of Cultural Sciences \\ Universitas Sebelas Maret \\ Jl. Ir. Sutami, Surakarta, Indonesia \\ wiratno.tri@gmail.com
}

\begin{abstract}
We often use booster in daily activities, especially in assertive speech acts that indirectly the resulting booster expression and it is no exception in a work of literary novel The ABC Murder (1936) by Agatha Christie which has been translated many times until to two decades, so that any booster can be changed or evolved. Thus, it raises the question of how the translator translates an assertive speech act word that contain booster to a two-decade translation and what technique is used. The data used The ABC Murder (1936) by Agatha Christie and two translated versions of 2017 and 1976. The approach used in this study is a qualitative method with document analysis purposive sampling with the classification of translation techniques used. The results show that 1) the booster shape evolved in 2017 and 1976. Furthermore, there were some booster words that shifted from answering to stating in The $\mathrm{ABC}$ Murder's novel and two versions of translation 2) Translation techniques that often appear are established equivalence and literal translation.
\end{abstract}

Keywords-booster; assertive speech act; two decade versions; translation techniques

\section{INTRODUCTION}

The emotional between the author and the reader is through flowing the text the author constructs. Metadiscourse is a true form of the embodiment of intertextuality, that the text is interdependent/related one word with others to produce meaning (Eriyanto, 2006; Hui \& Na, 2008; Hyland, 2005; Pérez-Llantada, 2003). Therefore, by removing the metadiscourse marker in a translated text the reader consequently will lose emotion between them and the writer cannot express their ideas, so the text is less interesting when followed (Gholami, et al, 2014). It should interest if we are reading need a marker to bind the emotions, then, the metadiscourse marker is directly facilitates between the author and the reader to realize the nature of the discussion between the two through a text.
Booster is one part of five part of the expression markers in metadiscourse marker by Hyland (2005) as an interactional marker. The embodiment of a booster in a text is a marker of certainty (Holmes, 1982 \& Hyland, 1999). The meaning of the booster of every speech in a literary text certainly affects the content and meaning of the text itself. In addition, the booster can be an explanation of the text content. But what if in a translation and its booster shifted the form and meaning of the translation to not a booster again in accordance with the source language text.

The study relates to booster has been widely discussed by some researcher, the research that examines the booster is still focused on research on variations in the use of booster in academic and pragmatic scopes (Demir, 2017, Navratilova, 2016, Salichah, et al, 2015; Kondowe, 2014; Yeganeh, et al, 2014; Sanjaya, 2013). In addition, the absence of which highlight areas of research related to linguistic translation in particular, by using a booster both in assessing the technique and quality of the translation. Although in the pragmatic field of the booster is examined to see the power to engage the reader in understanding the discourse through writing by using the expression of booster. Then, boosters are more widely used by authors on cross-cultural adjustments in academic discourse, academic writing, academic text, and through contributions researchers who want to publish their writings in international journals because of the differences in cultural culture that exist with the place where the writings will be published. Furthermore, some articles discuss the analysis of writing the use of booster in a research and newspaper article, and the last one that is often discussed is the difference between the men's and women's gender-related expressive in expressing hedges and boosters. So, until now not seen how the translation technique on booster used. Based on the review above, the researcher found that research gap has not studied before that would be a novelty and have not been reviewed by 
previous studies which translating booster expression in speech acts assertively in two decades the translated version.

The present study investigates the evolution form of booster and the translation technique used in translating booster of assertive speech acts at The ABC Murder novel and its two-translation version. The translation of booster expression in Agatha Christie's (1936) novel The ABC Murder and the comparison of booster expressions in two versions of the 2017 and 1976 versions using the socio-pragmatic approach. Moreover, it is to investigate whether the different strategies of using booster expressions differ after two decades by the translator. The paper has two research questions, they are: 1) how the evolution of booster form in assertive speech act in the novel of The ABC Murder? 2) what translation technique used in expressing booster on assertive speech act?

\section{LITERATURE REVIEW}

\section{A. Booster and Assertive Speech Act}

Booster is an expression in Hyland metadiscourse (2005), and the booster is a contradictory expression with hedging expression. Ordinarily, If the expression of hedging is more to doubt (uncertainty), conversely, the booster is an expression of a confidence booster of example claims to something or circumstance, such as: of course, sure, surely, always, true and others. (Holmes, 1982 and Hyland, 1999).

Assertive speech act is a part of speech acts proposed by Searle (1979: 12-20) in addition to speech acts directive, expressive, commissive and declarative. Assertive speech act is a speech that binds the speaker to the truth with the conviction that the speaker feels it is a fact and not based on his own. Moreover, assertive speech act has a function to state what he believes in the truth is. Then, the categories included in the assertive speech act include: stating, showing, answering, claiming, boasting, complaining.

The expression of the booster is often identified and used in academic scientific works that are used for making meaning of expression (Hyland, 1994 \& 2000). Through writing, the author interacts with the readers. Furthermore, still in terms of the use of the booster in academic writing, the same thing with Holmes which says that the booster refers to the lexical items created by the author to convince a situation. Moreover, Koutsantoni (2004) also added that the use of booster attendance was motivated by epistemological reasons and based on the results and the findings themselves and scientific discussions.

Boosters are manifested in the form of Lexico-grammatical markers adopted from Hyland's taxonomy (1996 \& 1998) and implemented in novels to be studied in this study, i.e.: 1) capital verbs (will, should and etc.), 2) lexical verbs thinking, showing, etc.), adverbs (obviously, obviously, etc.), adjectives (potential, clear, etc.) and phrases (in fact, in our view, etc. ).

In this study, especially in translation studies, the shift of booster expression can occur considering the translation context of the two novels is very far away from the cultural elements and contexts that exist in the society at that time. Thus, it is raising the question for the us, which translation is equivalence with the source text.

\section{B. Translation Techniques}

Translation technique is a real action performed by the translator in translating Source Text (ST) to Target Text (TT). It can be seen from its translation product. Accordingly, to Molina \& Albir (2002), interpretation means the procedure in analyzing and seeing how the correspondence is happening. The correspondence can be viewed and analyzed from the micro level on words, phrases, and clauses. Moreover,

The related translation techniques chosen by the translator will have a tremendous impact on the translation. In addition to translation techniques, there are several interrelated terms in translation e.g. procedures (Newmark, 1988); strategies (Machali, 2009, Pedersen, 2005), and techniques (Molina \& Albir, 2002). The strategy itself is the procedure chosen (at the time of translation) by the translator and usually, the term is expressed in-process research. The problem-solving process experienced by the translator occurs when translating in decision-making to find a counterpart. Then if you go to the procedure. The procedure itself is the rule in completing the existing stages (Nababan, 2016). So, the translation procedure means that the normative rule is applicable in translating the source text to the target text in this study, the translation technique used adopted the technique proposed by Molina \& Albir (2002).

\section{METHOD}

This study adopted qualitative research with the data collection by purposive sampling, by comparing the source text with the target text. The collected data are analyzed and classified and looked at the translation techniques used. Moreover, the interpretation of the data discussed in this study. The data source was the Novel of The ABC Murder written by Agatha Christie (1936) that used as a Source Text, then, two versions of Target Text, they are: Pembunuhan ABC (2017) and Mengenal si Pembunuh (1976). Furthermore, novel that became the document's data was first published in the UK by the Collins Crime Club on January 6, 1936, with 247 pages. The two translated versions from English to Indonesia, in the year 2017 published by PT Gramedia Pustaka Utama with 320 pages, which has now reached the eleventh edition and translated by Luci Dokubani. While the second version of the translation into Indonesia and also as a document data Mengenal si Pembunuh, published by Yayasan Karya Bhakti which is the first print in December 1976 with 255 pages. This second version is translated by Ugahari. The genre in this novel is a crime-fictional story because it tells of a detective who reveals a murder case.

The data is taken from the utterance expressed by the main player in the Novel both in the source Text and the target text in two versions. The booster taken as a criterion is in the form of words, phrases and clauses in the source text of 
assertive speech act. The main characters in this novel are Hercule Poirot, Arthur Hastings, and Chief Inspector.

\section{RESULT AND DISCUSSION}

In this section will be discussed and illustrated the form of booster in assertive speech act in the novel of The $A B C$ Murder written by Agatha Christie (1936) and its two translation versions; Pembunuhan ABC (2017) and Mengenal si Pembunuh (1976) accordingly to research question in this study. Moreover, this analysis used framework of pragmatic approach in reviewing translation result as describe previously.

According theory of Searle (1979: 12-20) the categories which included in the assertive speech are stating, showing, answering, claiming, boasting, complaining. These categories

A. The Evolution of Booster Form in Assertive Speech Acts in The Novel Of ABC Murder with Two Translation Versions

a. Stating

Stating is used by speakers to state something. In the crime novel detective stating is used to state the speech. Here is an example of stating used booster in the novel of The $A B C$ Murder and its two translations:

TABLE I. EXAMPLE I OF BOOSTER USED ON ASSERTIVE SPEECH ACT

\begin{tabular}{|c|c|c|}
\hline Source Text & Target Text1 (2017) & Target Text2 (1976) \\
\hline $\begin{array}{l}\text { "I did not kill } \\
\text { her! I did not } \\
\text { kill her!" [34] }\end{array}$ & $\begin{array}{l}\text { "Aku tidak membunuhnya! } \\
\frac{\text { Aku tidak membunuhnya!" }}{[33]}\end{array}$ & $\begin{array}{l}\text { "Aku tidak } \\
\text { membunuhnya ! Aku } \\
\underline{\text { tidak membunuhnya !" }} \\
{[27]}\end{array}$ \\
\hline
\end{tabular}

There is no change or shift in the translation results for 2017 and 1976. Among the two translation results included in the category of the booster on the stating. The booster lies in the word "did not" exist in the source text and on the target text tidak. however, it is different on the next stating, as follows:

TABLE II. EXAMPLE II OF BOOSTER USED ON ASSERTIVE SPEECH ACT

\begin{tabular}{|c|c|c|}
\hline Source Text & Target Text1 (2017) & Target Text2 (1976) \\
\hline $\begin{array}{l}\text { "It is all lies! } \\
\text { You are } \\
\text { goddamned } \\
\text { English pigs" } \\
{[34]}\end{array}$ & $\begin{array}{l}\text { "Semuanya dusta! } \\
\frac{\text { Kalian }}{\text { semua }} \text { Babanam- "[33] }\end{array}$ & $\begin{array}{l}\text { "Semua itu } \\
\text { kebohongan } \\
\text { babi- babi Inglah } \\
\underline{\text { keparat" }} \\
{[27]}\end{array}$ \\
\hline
\end{tabular}

Moreover, still in the same word that contains a booster expression on assertive acting speech acts, which depicts the husband's conviction of assured murder victim that he is not a killer in the underlined sentence with the embodiment of harsh and disrespectful words against Hercule who a famous detective is. Because the husband is suspected of involvement in the ABC murder case. Indeed, based on the storyline the victim's husband is hard and often said harshly to the victim who is his wife. According to the info on the novel from the neighbors, he likes to threaten to kill the victim but it's all just a common threat to his wife because he was often asked for money and need his wife to meet the lust for wildlife that likes drunkenness and gambling.

Moreover, there was an addition to the 1976 version with the demonstrative pronoun "itu" in the translation. then, there is no shift in meaning there are only possible additions according to the translator will help the reader to make the novel reading more natural.

Furthermore, different things are shown in the speech containing the next booster expression on the assertive speech act for example "You are goddamned English pigs". The results of the translation in 2017 show that it is clearly mentioned that the emphasis is on kalian semua. In the facts, the source text, there is no mention that there is semua, it is just "you are". Conversely, in contrast to the data on the 1976 target text, the more accurate the translation results by simply listing "Kau babi-babi Inggeris keparat!". The results of the data show that the booster is in the stating clauses and phrases.

\section{b. Showing}

Showing is used by speakers to express something used to show, be it gratitude, empathy, sympathy, feelings and so on novel in the novel of The ABC Murder and its two translations versions:

TABLE III. EXAMPLE III OF BOOSTER USED ON ASSERTIVE SPEECH ACT

\begin{tabular}{|c|c|c|}
\hline Source Text & Target Text1 (2017) & Target Text2 (1976) \\
\hline $\begin{array}{l}\text { "In truth I } \\
\text { sympathize } \\
\text { with you, but } \\
\text { what will you? } \\
\text { It is a } \\
\text { "question of } \\
\text { murder, is it } \\
\text { not? One has } \\
\text { to be very, } \\
\text { very careful." } \\
\text { [64-65] }\end{array}$ & $\begin{array}{l}\text { "Sebenarnya saya mengerti } \\
\text { perasaan Anda, tapi apa } \\
\text { Anda juga? Ini soal } \\
\text { pembunuhan, bukan? } \\
\text { Orang harus amat sangat } \\
\text { berhati-hati."[63] }\end{array}$ & $\begin{array}{l}\text { "Sebetulnya raja } \\
\text { bersimpati padamu, } \\
\text { tetapi apakah engkau? } \\
\text { Ini kan soal } \\
\text { pembunuhan ? Orang } \\
\text { harus sangat hati-hat.i" } \\
\text { [50] }\end{array}$ \\
\hline
\end{tabular}

The data above shows that the booster can serve to show the expression of something that is happening. Accordingly, context of the above conversation was made by Mr. Poirot to Mr. Albert Riddell concerning his wife's death in terms of interview sessions with witnesses and one of the witnesses interviewed was Mr. Albert Riddell. It was produced by $\mathrm{Mr}$. Poirot at Mr. Albert Riddell. 
The booster shown in assertive speech acts occurs in truth I sympathize. The booster itself is in the phrase in truth. Then, there was a booster shift in the 1976 and 2017 translations. In 1976, sebetulnya saja bersimpati padamu. The translation has a level of readability and acceptability that researchers feel is less natural, because diction in the translation felt stiff compared to the translation in 2017 is not accurate but acceptable is Sebenarnya saya mengerti perasaan Anda.

\section{c. Answering}

Answering's speech is used by speakers to answer questions from the spoken partner. As follows:

TABLE IV. EXAMPLE IV OF BOOSTER USED ON ASSERTIVE SPEECH ACT

\begin{tabular}{|c|c|c|}
\hline Source Text & Target Text1 (2017) & Target Text2 (1976) \\
\hline \begin{tabular}{|c|} 
"Oh, yes, they \\
have. Three tall \\
men with furtive \\
expressions- \\
four short men \\
with black \\
moustaches-two \\
beards - three fat \\
men-all \\
strangers-and \\
all, if I'm to \\
believe witnesses, \\
with sinister \\
expressions! I \\
wonder \\
somebody didn't \\
see a gang of \\
masked men with \\
revolvers while \\
they were about \\
it!" [61]
\end{tabular} & $\begin{array}{l}\text { "Oh ya, ada juga. Mereka } \\
\text { melihat tiga orang } \\
\text { bertubuh jangkung dengan } \\
\text { mimic yang mencurigakan } \\
\text { - empat orang bertubuh } \\
\text { pendek dengan kumis } \\
\text { berwarna gelap - dua } \\
\text { berjenggot - tiga orang } \\
\text { gemuk - semuanya orang } \\
\text { asing dan semuanya } \\
\text { berwajah seram. Bila saya } \\
\text { harus memercayai para } \\
\text { saksi mata! Saya heran, } \\
\text { tidak adakah orang yang } \\
\text { melihat sekelompok laki- } \\
\text { laki bertopeng membawa } \\
\text { pistol di sekitar daerah } \\
\text { ini!"[59] }\end{array}$ & $\begin{array}{l}\text { "Oh, ya, mereka telah } \\
\text { melihatnya. Tiga orang } \\
\text { jangkung dengan } \\
\text { airmuka licik - empat } \\
\text { orang pendek dengan } \\
\text { kumis hitam -- dua } \\
\text { berjenggot - tiga orang } \\
\text { gemuk - semuanya } \\
\text { orang asing - dan } \\
\text { semuanya, jika aku } \\
\text { boleh memberikan } \\
\text { kesaksian, dengan } \\
\text { airmuka suram ! Aku } \\
\text { bertanya-tanya } \\
\text { seseorang tidak } \\
\text { melihat sekomplotan } \\
\text { orang bertopeng } \\
\text { dengan revolver ketika } \\
\text { mereka di sekitar itu !" } \\
\text { [47] }\end{array}$ \\
\hline
\end{tabular}

The context of the situation that occurs in the above speech is when Mr. Poirot asked Inspector Glen an eyewitness account of the people around the scene of the murder. The speech above produced by Inspector Glen when asked about some things by Poirot.

Booster shown in assertive speech acts above is the answer of the Inspector Glen Oh, yes. The yes answer in the source text signifies the expression of a strong confidence booster on the complementary information that follows. However, there are changes to the target texts of 1976 and 2017. The more accurate in this case is found in the 1976 target text that is commensurate with the source text compared to 2017. Oh yes, and also, It is reasonably lack of accuracy in the source text spoken by Inspector Glen i.e. Oh yes, they have. It causes a shift of meaning there is also on the target text, it should be better to use Oh yes, there is! without any word addition too. If using Oh yes, and also, then the word also on this, make answering assertive speech act turned into stating with the addition of information as well.

\section{d. Claiming}

Claiming is used by speakers to express an acknowledgment of something that the speaker feels is true according to the obedient. As follows:

TABLE V. EXAMPLE V OF BOOSTER USED ON ASSERTIVE SPEECH ACT

\begin{tabular}{|c|c|c|}
\hline Source Text & Target Text1 (2017) & Target Text2 (1976) \\
\hline \begin{tabular}{|c|} 
"I've no doubt \\
that Crome is a \\
very efficient \\
officer, but, \\
frankly, he puts \\
my back up. That \\
air of his of \\
knowing best! \\
..'[161]
\end{tabular} & $\begin{array}{l}\text { "Saya tidak meragukan } \\
\text { kemampuan } \\
\text { sebagai perwira yang } \\
\text { efisien, tapi terus terang } \\
\text { dia mengecewakan saya. } \\
\text { Sikapnya seakan dia paling } \\
\text { tahu!.." [158] }\end{array}$ & $\begin{array}{lr}\text { "Saya tidak } & \text { sangsi } \\
\text { bahwa Crome adalah } \\
\text { seorang perwira yang } \\
\text { efisien, } \\
\text { terusterang, ia bikin } \\
\text { aku mundur. Lagaknya } \\
\text { yang } \\
\text { mengetahui } \\
{[127]}\end{array}$ \\
\hline
\end{tabular}

The context of the situation that occurs in the above speech is when Mr. Poirot asked Franklin Clarke about his displeasure with Crome. The speech above was produced by Franklin Clarke on Poirot.

The booster shown in the assertive speech act above is in Clarke's speech I've no doubt. The claim to the source text signifies a strong expression of the conviction that he has no doubt about Crome's ability as an officer in solving cases. However, there were changes to the target texts of 1976 and 2017. In 1976 I've no doubt translated into saya tidak sangsi which is observed in the source text is accurate. But, by 2017 there is an addition to the translation in addition to the word kemampuan it may be intended by the translator to clarify the sentence in the sentence that is in the source text novel. The kemampuan meant by the translator is the capability of Crome as an officer in which the source text is not explained whether it is capable or personal. Overall there is no shifter booster still on the assertive speech but there is the addition of the word as an explanatory variable in translated versions.

\section{B. Translation Technique Used in expressing booster on assertive speech act}

Translation techniques that exist in this research refers to translation techniques proposed by Molina \& Albir (2002).

a. The translation techniques used in the assertive speech act booster stating are illustrated in the following table:

TABLE VI. EXAMPLE I OF BOOSTER USED ON ASSERTIVE SPEECH ACT

\begin{tabular}{|c|c|c|}
\hline Source Text & Target Text1 (2017) & Target Text2 (1976) \\
\hline $\begin{array}{l}\text { "I did not kill } \\
\text { her! I did not } \\
\text { kill her!" [34] }\end{array}$ & $\begin{array}{l}\text { "Aku tidak membunuhnya! } \\
\frac{\text { Aku tidak membunuhnya!" }}{[33]}\end{array}$ & $\begin{array}{l}\text { "Aku } \frac{\text { tidak }}{\text { membunuhnya ! } \underline{\text { Aku }}} \\
\underline{\text { tidak membunuhnya !" }} \\
{[27]}\end{array}$ \\
\hline
\end{tabular}


In 2017 text targets the underlined booster translation technique above on the table to declare something is established equivalence. A established equivalence is a translation technique that uses an everyday expression or is prevalent in society. This technique is also similar to a literal technique. Similarly, in the 1976 translation that also uses the same technique that is commonly used.

b. The translation techniques used in the assertive speech act booster showing are illustrated in the following table:

TABLE VII. EXAMPLE VII OF BOOSTER USED ON ASSERTIVE SPEECH ACT

\begin{tabular}{|c|c|c|}
\hline Source Text & Target Text1 (2017) & Target Text2 (1976) \\
\hline $\begin{array}{l}\text { "In truth I } \\
\text { sympathize } \\
\text { with you, but } \\
\text { what will you? } \\
\text { It is a } \\
\text { "question of } \\
\text { murder, is it } \\
\text { not? One has } \\
\text { to be very, } \\
\text { very careful." } \\
{[64-65]}\end{array}$ & $\begin{array}{l}\text { "Sebenarnya saya mengerti } \\
\text { perasaan Anda, tapi apa } \\
\text { Anda juga? Ini soal } \\
\text { pembunuhan, bukan? } \\
\text { Orang harus amat sangat } \\
\text { berhati-hati."[63] }\end{array}$ & $\begin{array}{lr}\text { "Sebetulnya r saja } \\
\text { bersimpati padamu, } \\
\text { tetapi apakah engkau ? } \\
\text { Ini kan soal } \\
\text { pembunuhan ? Orang } \\
\text { harus sangat hati-hat.i" } \\
{[50]}\end{array}$ \\
\hline
\end{tabular}

In the target text of 2017 the underlined booster translation technique above on the table to indicate something is established equivalence. Furthermore, in the 1976 translation using literal translation techniques. A literal technique is a technique that switches verbatim from source to target language, and the translator does not relate to the context.

c. The translation techniques used in the assertive speech act booster answering are illustrated in the following table:

TABLE VIII. EXAMPLE VIII OF BOOSTER USED ON ASSERTIVE SPEECH ACT

\begin{tabular}{|c|c|c|}
\hline Text & Target Text1 (2017) & Target Text2 (1976) \\
\hline \begin{tabular}{|c|} 
"Oh, yes, they \\
have. Three tall \\
men with furtive \\
expressions- \\
four short men \\
with black \\
moustaches-two \\
beards - three fat \\
men-all \\
strangers-and \\
all, if I'm to \\
believe witnesses, \\
with sinister \\
expressions! I \\
wonder \\
somebody didn't \\
see a gang of \\
masked men with \\
revolvers while \\
they were about \\
it!" [61]
\end{tabular} & $\begin{array}{l}\text { "Oh ya, ada juga. Mereka } \\
\text { melihat tiga orang } \\
\text { bertubuh jangkung dengan } \\
\text { mimic yang mencurigakan } \\
\text { - empat orang bertubuh } \\
\text { pendek dengan kumis } \\
\text { berwarna gelap - dua } \\
\text { berjenggot - tiga orang } \\
\text { gemuk - semuanya orang } \\
\text { asing dan semuanya } \\
\text { berwajah seram. Bila saya } \\
\text { harus memercayai para } \\
\text { saksi mata! Saya heran, } \\
\text { tidak adakah orang yang } \\
\text { melihat sekelompok laki- } \\
\text { laki bertopeng membawa } \\
\text { pistol di sekitar daerah } \\
\text { ini!"[59] }\end{array}$ & $\begin{array}{l}\text { "Oh, ya, mereka telah } \\
\text { melihatnya. Tiga orang } \\
\text { jangkung dengan } \\
\text { airmuka licik - empat } \\
\text { orang pendek dengan } \\
\text { kumis hitam -- dua } \\
\text { berjenggot - tiga orang } \\
\text { gemuk - semuanya } \\
\text { orang asing - dan } \\
\text { semuanya, jika aku } \\
\text { boleh memberikan } \\
\text { kesaksian, dengan } \\
\text { airmuka suram ! Aku } \\
\text { bertanya-tanya } \\
\text { seseorang tidak } \\
\text { melihat sekomplotan } \\
\text { orang bertopeng } \\
\text { dengan revolver ketika } \\
\text { mereka di sekitar itu !" } \\
\text { [47] }\end{array}$ \\
\hline
\end{tabular}

In 2017 text targets the underlined booster translation technique above in the table for answering a question is established equivalence in spite of the addition. Furthermore, in the 1976 translation also used the technique in the prevalent, same as the translation in 2017.

d. The translation techniques used in the assertive speech act booster claiming are illustrated in the following table:

TABLE IX. EXAMPLE IX OF BOOSTER USED ON ASSERTIVE SPEECH ACT

\begin{tabular}{|c|c|c|}
\hline Source Text & Target Text1 (2017) & Target Text2 (1976) \\
\hline $\begin{array}{l}\text { "I've no doubt } \\
\text { that Crome is a } \\
\text { very efficient } \\
\text { officer, but, } \\
\text { frankly, he puts } \\
\text { my back up. That } \\
\text { air of his of } \\
\text { knowing best! } \\
. . \text {.'161] }\end{array}$ & $\begin{array}{l}\text { "Saya tidak meragukan } \\
\text { kemampuan } \\
\text { sebagai perwira yang } \\
\text { efisien,_tapi terus terang } \\
\text { dia mengecewakan saya. } \\
\text { Sikapnya seakan dia paling } \\
\text { tahu!.." [158] }\end{array}$ & $\begin{array}{lr}\text { "Saya tidak } & \text { sangsi } \\
\text { bahwa Crome adalah } \\
\text { seorang perwira yang } \\
\text { efisien, } \\
\text { terusterang, ia bikin } \\
\text { aku mundur. Lagaknya } \\
\text { yang } & \text { sangat } \\
\text { mengetahui r itu!.." } \\
{[127]}\end{array}$ \\
\hline
\end{tabular}

Both, the 2017 and 1976 translations use established equivalence technique, so there is no significant change despite the addition of information on the target text to the 2017 target text.

\section{CONCLUSION}

Accordingly, on the data, booster can have a role as a marker of assertive speech acts and clarify a speech that contains acting assertive act. Assertive speech acts not only have a function in everyday conversations but can also serve as explanatory information to tie the emotions between the author and the reader in a literary work, the novel.

Translation techniques that often appear on data that has been described both in the year 2017 and 1976 above are the technique of Established Equivalence and literal, so of course, if there is a different selection of techniques will produce different meanings.

This study is limited to only four of the six function of speech act are available so that it opens up opportunities for other researchers who wish to contribute to research related to booster expression on assertive speech acts.

The impact of the use of translation techniques is still not tested the quality of translation both accuracy, acceptability and readability, so that in later research needed rater and expert in the field of translation linguistics.

This study also contributes to the interpreter to consider the expression of the booster when translating speech related to assertive speech acts.

\section{Acknowledgment}

We would like to acknowledge the Rector of Universitas Muhammadiyah Palangkaraya, Dr. Bulkani, M.Pd on this research as his support to author, our families and also our promotor and co-promotor four our dissertation. 


\section{References}

Christie, Agatha. (1936). The ABC Murder. London: Collins Crime Club. Christie, Agatha. (1976). Mengenal si Pembunuh. (Ugahari, Trans). Bandung: Yayasan Karya Bhakti (Original work published 1936)

Christie, Agatha. (2017). Pembunuhan ABC. (Luci Dokubani, Trans). Jakarta: PT Gramedia Pustaka Utama (Original work published 1936)

Eriyanto. (2006). Analisis Wacana: Pengantar Analisis Teks Media. Yogyakarta: LKiS.

Gholami, Mehrnaz, et, al. (2014). An Investigation Of Metadiscourse Markers In English Medical Texts And Their Persian Translation Based On Hyland's Model. European Journal of English Language and Literature Studies Vol.2,No.2, pp.1-41, June 2014; www.ea-journals.org

Holmes, J. (1982). Expressing doubt and certainty in English. RELC Journal, 3: pp. 9-28.

Holmes, J. (1992). An introduction to sociolinguistics. London: Longman.

Hornby, Mary Snell. (1988). Translation Studies; An Integrated Approach. Amstredam/Philadelpia: John Benyamin Publishing Company.

Hui, J., \& Na, B. (2008). Use of metadiscourse in allocating SLA learners' attention. Sino-US English Teaching, 5, Whole No. 11

Hyland, K. (1998). Boosting, Hedging, and The Negotiation of Academic Knowledge. Text, 18(3) pp.349- 382.

Hyland, K. (1998a). Exploring corporate rhetoric. Metadiscourse in the CEO's letter. Journal of Business Communication, 35(2), pp. 224245.

Hyland, K. (1998b). Persuasion and context: The pragmatics of academic metadiscourse. Journal of Pragmatics, 30, pp. 437-455.

Hyland, K. (1999). Talking to students: Metadiscourse in introductory course books. English for Specific Purposes, 18(1), pp. 3-26.

Hyland, K. (2000). Disciplinary discourse: Social interactions in academic writing. London: Longman.

Hyland, K. (2004). Disciplinary interactions: Metadiscourse in L2 postgraduate writing. Journal of Second Language writing, 13, pp. 133-151.

Hyland, K. (2005). Metadiscourse: Exploring Interaction in Writing. London: Continuum.

Hyland, K., \& Tse, P. (2004). Metadiscourse in academic writing: a reappraisal. Applied Linguistics, 25 (2), 156-177.

Kondowe, Wellman. (2014). Hedging and Boosting as Interactional Metadiscourse In Literature Doctoral Dissertation Abstracts. International Journal of Language Learning and Applied Linguistics World (IJLLALW), Volume 5 (3), March 2014; pp. 214-221, Www.Ijllalw.Org.

Koutsantoni, D. (2004). Attitude, certainty and allusions to common knowledge in scientific research articles. In Journal of English for Academic Purposes, Vol. 3, pp. 163-182, DOI: https://doi.org/10.1016/j.jeap.2003.08.001

Machali, R. (2009). Pedoman bagi penerjemah. Bandung: Penerbit Kaifa.

Molina, Lucia and Hurtado Albir, A. (2002). "Translation Techniques Revisited: A Dynamic and Functionalist Approach" in Meta: Journal des Traducteur/Meta: Translators' Journal. XLVII, No.4 Pp. 498-512.

Nababan, M.R. (2016). Teori Menerjemahkan Bahasa Inggris. Yogyakarta: Pustaka Pelajar.

Newmark, P. (1988). A Textbook of Translation. New York: Prentice Hall Ltd.

Pedersen, J. (2005). How is Culture Rendered in Subtitles? in H. GerzymischArbogast \& S. Nauert (Eds.). Marie Curie EU High Level Scientific Conferences Series: Challenges of Multidimensional Translation (pp. 113-130). Saarbrücken: Advanced Translation Research Centre (ATRC).

Salichah, Imraatu, Et, Al. (2015). Hedges and Boosters in Undergraduate Students' Research Articles. Jurnal Pendidikan Humaniora. Vol. 3 No. 2, pp. 154-160, June 2015; Http://Journal.Um.Ac.Id/Index.Php/Jph

Sanjaya, I.N.S. (2013). Hedging and Boosting In English And Indonesian Research Articles (doctoral dissertation). The Pennsylvania State University the Graduate School College of the Liberal Arts; https://etda.libraries.psu.edu/catalog/18351
Searle, J.R. (1979) Expression and Meaning. London, New York, Melbourne: Cambridge University Press.

Yeganeh, M.T, Et, Al. (2014). Hedge and Booster in Newspaper Articles on Iran's Presidential Election: A Comparative Study of English And Persian Articles. $2^{\text {nd }}$ Global Conference on Linguistics and Foreign Language Teaching, Dubai - United Arab Emirates, December $11 \quad-\quad 13, \quad 2014$; $\mathrm{Http}: / / \mathrm{Www}$. Sciencedirect.Com/ 